\title{
Creep Parameters and Dislocation Substructure in AISI 316 Austenitic Stainless Steel From $600^{\circ} \mathrm{C}$ to $800^{\circ} \mathrm{C}$
}

\author{
Sergio Neves Monteiro ${ }^{a}$, Fernanda Santos da Luz ${ }^{a}$, Wagner Anacleto Pinheiro ${ }^{a}$, Luiz Paulo \\ Mendonça Brandão ${ }^{a}$, Fábio de Oliveira Braga ${ }^{a}$, Foluke Salgado de Assis ${ }^{a}$ \\ a Military Institute of Engineering (IME), Department of Materials Science, Praça General Tibúrcio, 80, \\ Praia Vermelha, Urca, CEP 22290-270, Rio de Janeiro, RJ, Brazil
}

Received: December 11, 2016; Revised: May 2, 2017; Accepted: June 8, 2017

\begin{abstract}
Stainless steels are well known by their corrosion resistance. The austenitic types, in particular, are also applied as structural components in engineering systems operating at high temperatures such as nuclear reactors, petrochemical furnaces and turbines. For these applications operational temperatures may go up to $800^{\circ} \mathrm{C}$. Under constant load applications the main mechanism of failure, which would limit the material's life, is creep. In the present work creep parameters were evaluated in the high temperature interval of 600 to $800^{\circ} \mathrm{C}$ for an AISI 316 austenitic stainless steel. Dislocation substructures were observed by transmission electron microscopy in creep ruptured specimens. Two distinct mechanisms of dynamic strain aging and dynamic recovery associated with different values for the power law exponent $\mathbf{n}$ and the Arrhenius activation energy $\mathbf{Q}$ for creep were verified below and above $700^{\circ} \mathrm{C}$, respectively.
\end{abstract}

Keywords: Creep test, AISI 316 stainless steel, dislocation substructure, high temperature mechanisms

\section{Introduction}

Creep behavior of metals and alloys has been attracting considerable interest since the beginning of the twentieth century owing to technological developments that require high temperature operational conditions ${ }^{1}$. These temperatures are usually in the range of 0.40 to 0.65 of the absolute melting temperature, $\mathrm{T}_{\mathrm{m}}$. Today, among these high temperature technological developments stand gas turbines, nuclear reactors and petrochemical furnaces. Applications associated with these systems require temperature resistant materials such as ceramics, superalloys and stainless steels. In particular, austenitic stainless steels combine both corrosion and creep resistance that are desirable for systems operating under aggressive environments like the aforementioned ones. The type AISI 316 austenitic stainless steel (316 steel for short) is a common choice since its melting temperature around $1400^{\circ} \mathrm{C}$ allows applications subjected to stress up to $800^{\circ} \mathrm{C}$ $\left(\sim 0.65 \mathrm{~T}_{\mathrm{m}}\right)^{2}$. Indeed, 316 steel has been applied in Generation IV (GEN IV) nuclear reactors, such the metal-cooled fast breeder reactors and high temperature reactor ${ }^{3-8}$ as well as other high temperature applications ${ }^{9,10}$.

For all applications involving creep, the characterization of basic parameters such as the creep rate, stress dependent exponent and activation energies is of relevance to allow an estimative of the materials operational life. The minimum creep rate $\left(\dot{\varepsilon}_{\mathrm{S}}\right)$, experimentally obtained as the slope of stage

* e-mail: snevesmonteiro@gmail.com
II in the strain vs. time creep curve, is probably the most important parameter. A general state equation proposed by Mukherjee et al. ${ }^{11}$ relates $\dot{\varepsilon}_{\mathrm{S}}$ to other creep parameters

$$
\dot{\varepsilon}_{\mathrm{S}}=\frac{\text { A.E.b }}{\mathrm{k} \cdot \mathrm{T}} \cdot \mathrm{D}_{0} \cdot \exp \left(\frac{-\mathrm{Q}}{\mathrm{R} \cdot \mathrm{T}}\right) \cdot\left(\frac{\mathrm{b}}{\mathrm{d}}\right)^{\mathrm{p}} \cdot\left(\frac{\sigma}{\mathrm{E}}\right)^{\mathrm{n}}
$$

where $\mathbf{A}$ is a constant, $\mathbf{E}$ the elastic modulus, $\mathbf{k}$ the Boltzmann constant, $\mathbf{T}$ the absolute temperature, $\mathbf{D}_{\mathbf{0}}$ is a constant independent of temperature, $\mathbf{R}$ the gas constant, $\mathbf{Q}$ the activation energy, $\mathbf{b}$ the Burgers vector, $\mathbf{d}$ the grain size, $\mathbf{p}$ the inverse grain-size exponent, $\boldsymbol{\sigma}$, the general stress, which depends of applied load, and $\mathbf{n}$ the stress exponent.

The apparently complex equation (1) might be simplified for common applied conditions involving the same steel, with unchanged grain size d, operating at a constant temperature, T. In this case equation (1) may be given as the so-called power law:

$$
\frac{\dot{\varepsilon}}{\mathrm{D}}=\mathrm{K} \cdot\left(\frac{\sigma}{\mathrm{E}}\right)^{\mathrm{n}}
$$

where $\mathbf{D}$ is the diffusivity and $\mathbf{K}$ is a constant involving the other terms in equation (1). The value of $\mathbf{n}$ is sometimes referred as the Norton exponent and thought to be associated with distinct creep mechanisms that could also be related to the value of $\mathbf{Q}$ in equation (1). For the interested reader, the main creep mechanisms in metallic materials have been listed as $^{1}$ : diffusion creep, climb of dislocations, grain boundary sliding and dislocation glide. 
The creep behavior of 316 steel, in particular, has been investigated since the 1960s. Early works of Garofalo et al. ${ }^{12,13}$ found in 316 steel a creep activation energy of $Q=314 \mathrm{~kJ} /$ mol in the temperature range between 593 to $830^{\circ} \mathrm{C}$, which was attributed to self-diffusion in face-centered cubic (FCC) $\gamma$ iron. In principle this could be associated with a vacancy controlled climb of dislocations type of mechanism. Mazza and Willoughby ${ }^{14}$ reported an activation energy of $565 \mathrm{~kJ} / \mathrm{mol}$ at $600^{\circ} \mathrm{C}$, which might be assigned to chromium diffusion. Below $700^{\circ} \mathrm{C}$, Barnby ${ }^{15}$ found evidence of aging-controlled creep in 316 steel, probably corroborating the $\mathrm{Cr}$ diffusion. In a later work, Kestenbach et al. ${ }^{16}$ presented the dislocation substructure developed during creep of 316 steel between 600 and $800^{\circ} \mathrm{C}$. They found that the high stresses dislocation climb was replaced by glide, which does not depend on diffusion. Moreover, above $650^{\circ} \mathrm{C}$ the substructure changed from cells to elongated subgrains.

Recent works on creep behavior of 316 steel have emphasized the combined effect of creep-fatigue in the steel operational life based on damage and crack propagation ${ }^{17-25}$. In spite of relevant results, the works on high temperature creep of 316 steel have not yet provided a comprehensive analysis of mechanical parameters and dislocation substructure in terms of creep mechanisms. In the present work the creep mechanisms in 316 steel tested from 600 to $800^{\circ} \mathrm{C}$ were assessed and associated with stress-related parameters and dislocation substructure.

\section{Materials and Methods}

The basic investigated material was an AISI type 316 austenitic steel (316 steel for short) supplied by Sandvik in the form of hot-rolled bar with $10 \mathrm{~mm}$ in diameter. The chemical composition of the steel is given in Table 1.

The as-received 316 steel bar was solution treated at $1100^{\circ} \mathrm{C}$ for one hour under vacuum. A grain size of about $80 \mu \mathrm{m}$ was obtained. Cylindrical specimens were machined from the bar with gage dimensions of $4 \mathrm{~mm}$ in diameter and $24 \mathrm{~mm}$ in length as per ASTM E139 ${ }^{26}$ and ASTM E8 $8^{27}$ standards. Before testing, specimens were electropolished in a $6 \%$ perchloric acid solution in ethanol to smooth marks from the machining operation. Constant load creep tests were conducted under vacuum in a tubular furnace of an Instron system at temperatures in the interval from 600 to $800^{\circ} \mathrm{C}$. Before testing the specimens were soaked for two hours at the proper temperature without applied load. During tests the temperature was held constant within $5^{\circ} \mathrm{C}$ and the strain continuously registered with an accuracy of $5 \times 10^{-4}$. Samples for transmission electron microscopy (TEM) observation were spark-cut from tested specimens. Discs of these samples were thinned by electropolishing at $3 \mathrm{~V}$ in the aforementioned solution until the first hole was obtained with convenient areas for transmission electron imaging. A TEM $200 \mathrm{kV}$ Jeol microscope was used to observe dislocation substructures.

\section{Results and Discussion}

Strain versus time creep curves were directly recorded by the machine in digital form and processed by computer to allow determination of true strain $(\varepsilon)$, the corresponding true stress $(\sigma)$ and the time derivative $\dot{\varepsilon}=\mathrm{d} \varepsilon / \mathrm{dt}$ (creep rate) at each point of the curve. The time variation of creep rate displayed the typical curve with a short stage II associated with secondary creep. The minimum obtained in the continuous interpolation of $\dot{\varepsilon}$ versus $t$ computer data was chosen as the secondary creep rate, $\dot{\varepsilon}_{\mathrm{S}}$.

Figure 1 shows the logarithmic dependence of $\dot{\varepsilon}_{\mathrm{S}}$ with $\sigma$, corresponding to the constant load, for different investigated temperatures. In spite of some scatter in the data points for each temperature in Figure 1, a consistent linear relationship was found between $\log \dot{\varepsilon}_{s}$ and $\log \sigma$. These straight lines indicate an experimental creep behavior associate with the power law, equation (2). As a consequence, the slopes of straight lines in Figure 1 correspond to the value of the exponent $\mathbf{n}$.

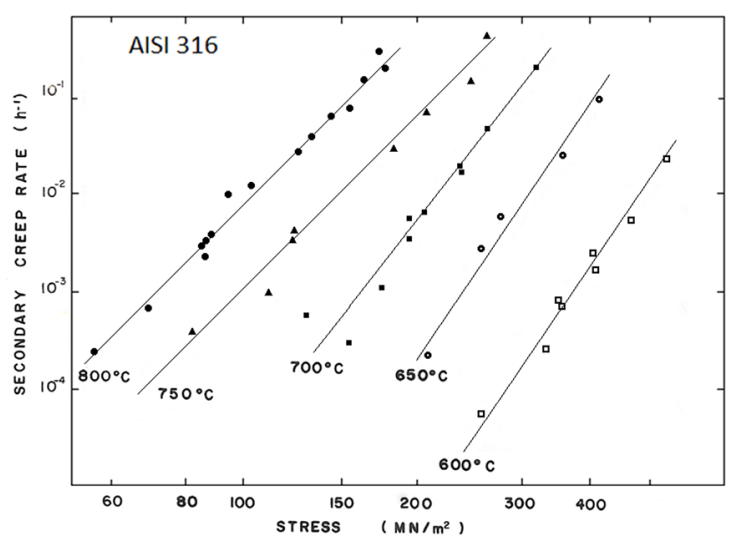

Figure 1. Variation of the secondary creep rate with true stress for 316 steel.

Figure 2 shows the graphs of $\mathbf{n}$ as a function of the temperature. In this figure it is important to note that at 600 and $650^{\circ} \mathrm{C}$, the values of $\mathbf{n}$ are around 9 , while at 750 and $800^{\circ} \mathrm{C}$ around 6 . In principle, this change in value of $\mathbf{n}$ from 9 , below $700^{\circ} \mathrm{C}$, to 6 , above $700^{\circ} \mathrm{C}$, might be related to change in creep mechanism. Although mechanisms have been proposed in previous works ${ }^{12-16}$, an association with mechanical creep parameters is yet to be discussed.

Table 1. Chemical composition of the investigated AISI type 316 stainless steel.

\begin{tabular}{cccccccc}
\hline $\mathrm{C}$ & $\mathrm{Cr}$ & $\mathrm{Ni}$ & $\mathrm{Mo}$ & $\mathrm{Mn}$ & $\mathrm{Si}$ & $\mathrm{P}$ & $\mathrm{S}$ \\
\hline 0.07 & 18.3 & 12.5 & 2.55 & 1.72 & 0.50 & 0.026 & 0.014 \\
\hline
\end{tabular}




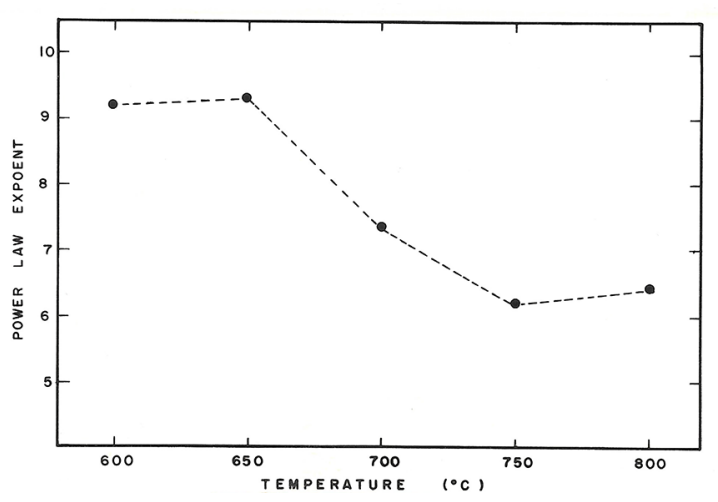

Figure 2. Temperature dependence of the power law exponent $\mathbf{n}$.

One relevant question might be raised regarding mechanisms. Which state variable, temperature or stress, is more appropriate to characterize creep mechanism? Several early works ${ }^{11,14,15}$ and a recent publication ${ }^{2}$ emphasized the importance of temperature, while others ${ }^{12,13,16}$ indicated that stress could better represent the participation of creep mechanisms. The reader may notice that equation (1) discloses the influence of both $\mathbf{T}$ and $\boldsymbol{\sigma}$ in the creep rate. This is not clear in equation (2). Moreover, one must remember that materials properties, such as diffusion coefficient, $\mathbf{D}$, and elasticity modulus, $\mathbf{E}$, are temperature dependent. Therefore, in order to take these factors into account, the experimental data in Figure 1 was rationalized as $\dot{\varepsilon}_{\mathrm{S}} / \mathrm{D}$ and $\sigma / \mathrm{E}$ and plotted in log-log scale for all investigated temperatures. Figure 3 shows the variations of $\dot{\varepsilon}_{\mathrm{s}} / \mathrm{D}$ with $\log \sigma / \mathrm{E}$ for creep tests of 316 steel from 600 to $800^{\circ} \mathrm{C}$. In this figure dispersion bands were drawn limiting all experimental points.

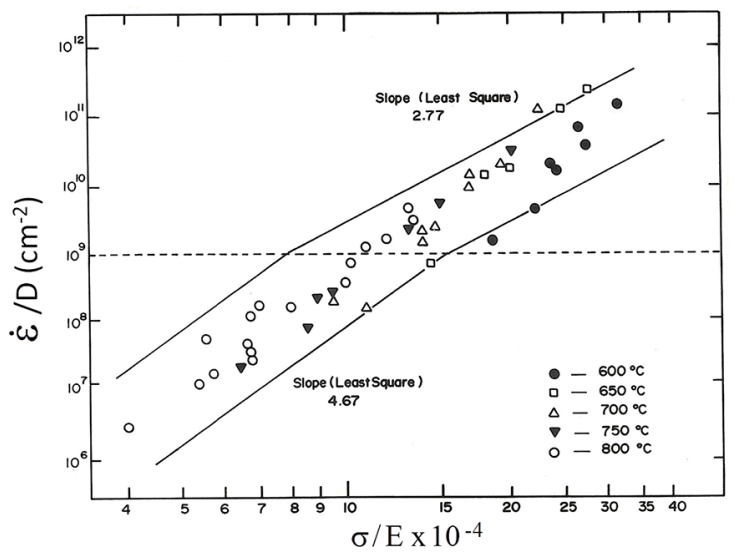

Figure 3. Variation of $\log \dot{\varepsilon}_{\mathrm{s}} / \mathrm{D}$ with $\log \sigma / \mathrm{E}$ for the high temperature creep $\left(600^{\circ} \mathrm{C}-800^{\circ} \mathrm{C}\right)$ in 316 steel.

A statistical analysis indicated that points above $\dot{\varepsilon}_{\mathrm{s}} / \mathrm{D}=$ $10 \% \mathrm{~cm}^{2}$ (dashed horizontal line) would be adjusted to a linear relationship with slope of 2.77. Below the dashed horizontal line, experimental points are adjusted to a straight line with slope of 4.67. These are subtle adjustments but statistically more consistent than a single straight line adjusting all points. Therefore, two bands with different slopes, above and below the dashed horizontal line in Figure 3 are limiting the experimental points. This change in slope might be an indication that two distinct creep mechanisms are operating not only with change in strain rate (vertical scale) but also by changing the stress (horizontal scale). Based on the results in Figure 3, this change in creep mechanisms would be occurring at a stress level around $\sigma / \mathrm{E}=10^{-3}$. In addition to possible change in creep mechanism at high temperature, Figure 2, as well with change in strain rate and stress, Figure 3, dislocation substructures also collaborate to a possible change.

Figure 4 illustrates typical dislocation structures at $600^{\circ} \mathrm{C}$ and $750^{\circ} \mathrm{C}$ for creep test at moderate stress levels. The substructures at $600^{\circ} \mathrm{C}$, Figure $4 \mathrm{a}$, are composed of fine cells with massive tangles of dislocations, which is a characteristics of dynamic strain aging ${ }^{2,15}$. The substructure at $750^{\circ} \mathrm{C}$, Figure $4 \mathrm{~b}$, reveals evidence of effective dynamic recovery with formation of aligned cell walls that are related to the beginning of subgrains ${ }^{16}$. Indeed, the values of the stress exponent $\mathbf{n}$ shown in Figure 2 are consistent with those between 4 and 7, usually obtained for vacancy self diffusion rate controlled creep ${ }^{11}$.

\section{Final Remarks}

The experimental results on creep parameters, Figure 2 and 3 , as well as dislocation substructures developed at high temperatures of 600 to $800^{\circ} \mathrm{C}$ in 316 steel disclosed for the first time evidence of two mechanisms. The change from one mechanism to another occurred either with temperature, around $700^{\circ} \mathrm{C}$, shown in Figure 2, or with strain rate at $\dot{\varepsilon}_{\mathrm{s}} / \mathrm{D}$ $\sim 10^{9} / \mathrm{cm}^{2}$ or with stress at $\sigma / \mathrm{E} \sim 10^{-3}$, shown in Figure 3 . Below this threshold limits, dynamic strain aging (DSA) is probably the predominant mechanism, as suggested in both earlier ${ }^{15}$ and recent ${ }^{2}$ publications. The tangled substructure in Figure 4a corroborates the DSA mechanism of dislocation interaction with solute atoms ${ }^{1}$. Above the aforementioned threshold limits, DSA is over and dynamic recovery predominates in association with a tendency of subgrains formation shown in Figure 4b. In particular, when $\dot{\varepsilon}_{\mathrm{s}} / \mathrm{D}>$ $10^{9} / \mathrm{cm}^{2}$ and $\sigma / \mathrm{E}>10^{-3}$, thermally activated dislocation glide becomes the creep rate controlling mechanisms ${ }^{1,16}$. Below these values, dislocation climb might predominate ${ }^{1}$.

The combined experimental values of $\dot{\varepsilon}_{\mathrm{S}}$ and $\mathrm{T}$ in equation (1) were used to calculated the activation energies, based on the Arrhenius relationships, associated with the different creep mechanisms. For points below $700^{\circ} \mathrm{C}$, the average activation energy was found $\mathrm{Q}=505 \mathrm{~kJ} / \mathrm{mol}$, while above $700^{\circ} \mathrm{C}$, as $\mathrm{Q}$ $=377 \mathrm{~kJ} / \mathrm{mol}$. The higher value of $\mathbf{Q}$ below $700^{\circ} \mathrm{C}$ might be assigned to diffusion of substitutional atoms, such as $\mathrm{Cr}$. This is in agreement with the aging-controlled creep proposed by Barnby $^{15}$. It also corroborates the occurrence of DSA in 316 steel. On the other hand, the comparatively lower value of $\mathbf{Q}$ above $700^{\circ} \mathrm{C}$ is not far from the self-diffusion of $\mathrm{Fe}$ in the steel FCC lattice. This would be associated with vacancy 


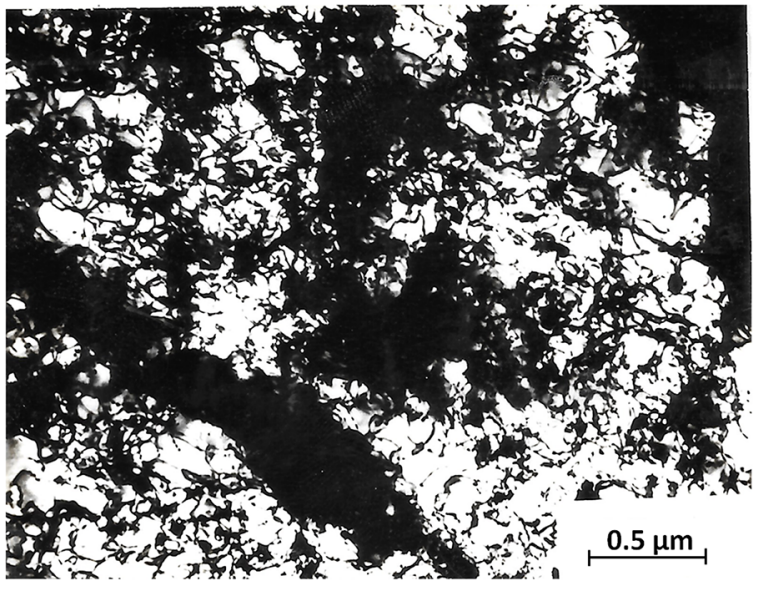

(a) $600^{\circ} \mathrm{C}$

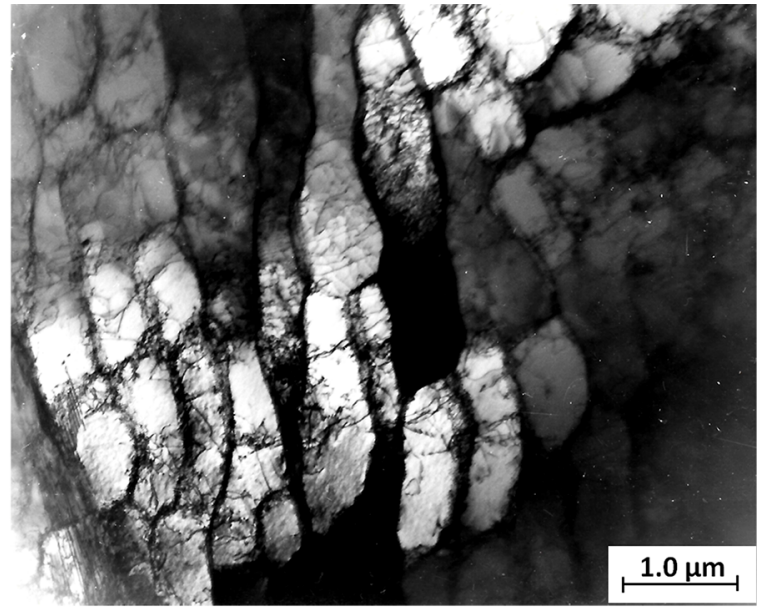

(b) $750^{\circ} \mathrm{C}$

Figure 4. TEM fractographs of dislocation substructures at: (a) $600^{\circ} \mathrm{C}$ and (b) $750^{\circ} \mathrm{C}$ in creep tested 316 steel.

motion responsible for dislocation climb, which contributes to dynamic recovery mechanisms.

\section{Conclusions}

- The evaluation of creep parameters of AISI type 316 austenitic stainless steel in the high temperature interval of 600 to $800^{\circ} \mathrm{C}$ disclosed experimental evidence of two mechanisms.

- These creep mechanisms were revealed in association with changes in temperature, creep rate and stress. The threshold limits from one mechanism to another were $\mathrm{T}=700^{\circ} \mathrm{C}, \dot{\varepsilon}_{\mathrm{s}} / \mathrm{D}=10^{9} / \mathrm{cm}^{2}$ and $\sigma / \mathrm{E}=10^{-3}$.

- Tangled dislocation substructures below $700^{\circ} \mathrm{C}$ and tendency of subgrains formation above, together with corresponding values of activation energies of 505 and $377 \mathrm{~kJ} / \mathrm{mol}$, respectively, suggest a dynamic strain aging below and climb or glide related dynamic recovery above $700^{\circ} \mathrm{C}$.

\section{Acknowledgements}

The authors thank the support to this investigation by the Brazilian agencies: CNPq, FAPERJ and CAPES.

\section{References}

1. Meyers MA, Chawla KK. Mechanical Behavior of Materials. $2^{\text {nd }}$ ed. Cambridge: Cambridge University Press; 2009. p. 653-688.

2. Christopher J, Chodhary BK. On the assessment of tensile work hardening behaviour of type $316 \mathrm{~L}(\mathrm{~N})$ austenitic stainless steel in the framework of $\theta \sigma_{d}$ vs. $\sigma_{d}$ using flow stress contribution from dislocations. International Journal of Pressure Vessels and Piping. 2016;146:151-160.
3. Veternikova JS, Degmova J, Pekarcikova M, Simko F, Petriska M, Skarba M, et al. Thermal stability study for candidate stainless steel of GEN IV reactors. Applied Surface Science. 2016;387:965-970.

4. Lee HY. Comparison of elevated temperature design codes of ASME Subsection NH and RCC-MRx. Nuclear Engineering and Design. 2016;308:142-153.

5. Nakae N, Ozawa T, Ohta H, Ogata T, Sekimoto H. An approach for evaluating the integrity of fuel applied in Innovative Nuclear Energy Systems. Journal of Nuclear Materials. 2014;446(1-3):1-9.

6. Parthasarathi NL, Borah U, Albert SK. Effect of temperature on sliding wear of AISI $316 \mathrm{~L}(\mathrm{~N})$ stainless steel - Analysis of measured wear and surface roughness of wear tracks. Materials \& Design. 2013;51:676-682.

7. Mathew MD. Evolution of creep resistant 316 stainless steel for sodium cooled fast reactor applications. Transactions of the Indian Institute of Metals. 2010;63(2):151-158.

8. Takahashi Y, Shibamoto H, Inoue K. Long-term creep rupture behavior of smoothed and notched bar specimens of low-carbon nitrogen-controlled 316 stainless steel (316FR) and their evaluation. Nuclear Engineering and Design. 2008;238(2):310-321.

9. Raj B, Mudali UK, Vasudevan M, Shankar P. Current status of AISI type $304 \mathrm{LN}$ and $316 \mathrm{LN}$ austenitic stainless steels. Transactions of the Indian Institute of Metals. 2002;55(4):131-147.

10. Sourmail T. Precipitation in creep resistant austenitic stainless steels. Materials Science and Technology. 2001;17(1):1-14.

11. Mukherjee AK, Bird JE, Dorn JE. Experimental correlations for high-temperature creep. ASM Transactions Quarterly. 1969;62:155-179.

12. Garofalo F, Whitmore RW, Domis WF, von Gemmingen F. Creep and Creep-Rupture Relationships in an Austenitic Stainless Steel. Transactions of the Metallurgical Society of AIME. 1961;221:310-319.

13. Garofalo F. An empirical relation defining the stress dependence of minimum creep rate in metals. Transactions of the Metallurgical Society of AIME. 1963;227:351-369. 
14. Mazza JA, Willoughby G. Structural changes and creep mechanisms in type 316 steel at $600^{\circ} \mathrm{C}$. Journal of the Iron and Steel Institute. 1966;204:718-726.

15. Barnby JT. Effect of strain aging on creep of an AISI 316 austenitic stainless steel. Journal of the Iron and Steel Institute. 1966;204:23-27.

16. Kestenbach H-J, Krause W, Silveira TL. Creep of 316 stainless steel under high stresses. Acta Metallurgica. 1978;26(5):661-670.

17. Hormozi R, Biglari F, Nikbin K. Experimental and numerical creep-fatigue study of Type 316 stainless steel failure under high temperature LCF loading condition with different hold time. Engineering Fracture Mechanics. 2015;141:19-43.

18. Yan XL, Zhang XC, Tu ST, Mannan SL, Xuan FZ, Lin YC. Review of creep-fatigue endurance and life prediction of 316 stainless steels. International Journal of Pressure Vessels and Piping. 2015;126:17-28.

19. Wen JF, Tu ST, Gao XL, Reddy JN. New model for creep damage analysis and its application to creep crack growth simulations. Materials Science and Technology. 2014;30(1):32-37.

20. Holmström S, Auerkari P. A robust model for creep-fatigue life assessment. Materials Science and Engineering: A. 2013;559:333-335.

21. Carroll MC, Carroll LJ. Fatigue and creep-fatigue deformation on an ultra-fine precipitate strengthened advanced austenitic alloy. Materials Science and Engineering: A 2012;556:864-877.
22. Gorash Y, Altenbach H, Lvov G. Modeling of high-temperature inelastic behaviour of the austenitic steel AISI type 316 using a continuum damage mechanics approach. The Journal of Strain Analysis for Engineering Design. 2012;47(4):229-243.

23. Yoda R, Yokomaku T, Tsuji N. Plastic deformation and creep damage evaluations of type 316 austenitic stainless steels by EBSD. Materials Characterization. 2010;61(10):913-922.

24. Gao N, Brown MW, Miller KJ, Reed PAS. An investigation of crack growth behaviour under creep-fatigue condition. Materials Science and Engineering: A. 2005;410-411:67-71.

25. Wilshire B, Willis M. Mechanisms of strain accumulation and damage development during creep of prestrained 316 stainless steels. Metallurgical and Materials Transactions A. 2004; 35 : 563-571.

26. ASTM International. ASTM E139-11 - Standard Test Methods for Conducting Creep, Creep-Rupture, and Stress-Rupture Tests of Metallic Materials. West Conshohocken: ASTM International; 2011.

27. ASTM International. ASTM E8 / E8M - 16: Standard Test Methods for Tension Testing of Metallic Materials. West Conshohocken: ASTM International; 2016. 